\title{
CONTRIBUTION TO THE KNOWLEDGE OF DRAGONFLY FAUNA (INSECTA: ODONATA) OF BJELOVAR AREA, CROATIA - RESULTS OF A FOUR-YEAR PHOTOGRAPHIC STUDY
}

\author{
Monika Veljković \\ Gornje Plavnice 56, 43000 Bjelovar, Croatia (monika.veljkovic1@gmail.com)
}

Veljković, M.: Contribution to the knowledge of dragonfly fauna (Insecta: Odonata) of Bjelovar area, Croatia - results of a four-year photographic study. Nat. Croat., Vol. 30, No. 1, 161-172, Zagreb, 2021.

This paper gives a list of 10 species from five Odonata families observed in Gornje Plavnice near Bjelovar, Croatia in a period between the $18^{\text {th }}$ of June 2017 and the $11^{\text {th }}$ of August 2020. This photographic research, conducted along the Jarak Pond and on the surrounding meadows, agricultural land and forest edge in Gornje Plavnice, represents a contribution to the knowledge of dragonfly fauna of the Bjelovar-Bilogora area as well as of Croatia as a whole.

Key words: Odonata, fauna, Gornje Plavnice, Bjelovar-Bilogora area

Veljković, M.: Doprinos poznavanju faune vretenaca (Insecta: Odonata) na području Bjelovara, Hrvatska - rezultati četverogodišnjeg fotografskog istraživanja. Nat. Croat., Vol. 30, No. 1, 161-172, Zagreb, 2021.

Rad donosi popis 10 vrsta vretenaca iz 5 porodica zabilježenih u Gornjim Plavnicama blizu grada Bjelovara, Hrvatska, u razdoblju od 18. lipnja 2017. do 11. kolovoza 2020. godine. Ovo istraživanje, temeljeno na fotografijama, provedeno je uz ribnjak "Jarak" te na okolnim livadama, poljoprivrednim površinama i rubnom području šume u Gornjim Plavnicama te predstavlja doprinos poznavanju faune vretenaca bjelovarsko-bilogorskog područja i Hrvatske.

Ključne riječi: Odonata, fauna, Gornje Plavnice, bjelovarsko-bilogorsko područje

\section{INTRODUCTION}

Many dragonfly observers avoid collecting and preparation of dragonfly individuals because of personal ethical or legal reasons, which raises the question of a substitute for the collection of voucher specimens to ensure the credibility of species identification (SCHмIDT, 1982; DAY et al., 2012). Although in the absence of voucher specimens, the correct identification of any adult dragonfly specimens observed cannot be guaranteed, photography offers some possibilities (SCHMIDT, 1982). The photographic approach (by taking only decent pictures, without sampling the animal) promises to be of immense help in the inventorying of dragonfly species for its reliability in species identification (JANRA, 2018). The ease of digital photography and increasing public interest in research into nature result in a rapidly increasing collection of photographic records of Odonata that provide data useful to science (DAY et al., 2012). Many different web platforms (e.g. BugGuide, iNaturalist, Croatian checklist of Odonata, etc.) enable such photographic records to become a good basis for further research. 
When using "dragonfly watching" as a basis for faunistic records, the great challenge is to filter out the noise of unreliable identification from photographs because photographs are often taken from the wrong angle, or use the wrong plane of focus to show key characteristics such as particular veins or other details. (SCHMIDT, 1982; DAY et al., 2012). Knowledge of differential characteristics usable for voucher photos (SCHMIDT, 1982) as well as guides for the identification of dragonflies by sight and by photographs (SCHMidT, 1995; GALliani et al., 2017) facilitate species identification from photographs. Reliable photographic records still appear to be biased towards common, photogenic and widespread species (DAY et al., 2012). However, seven Odonata species were recorded from Thailand for the first time from records mostly based on credible photographs (SRIBAL et al., 2018). Also, SEEHAUSEn et al. (2018) presented an annotated list of 28 Odonata species from Timor Island based on 464 records via photographs and 56 specimens held in collections at the Museum and Art Gallery of the Northern Territory, Darwin, Australia and the Wiesbaden Museum, Germany. Odonata species are tied to freshwater environments that are degrading because of the changes caused by human impact, so reducing to a minimum or completely the collection of specimens for their identification is nowadays not only possible but even desirable (GaLliani et al., 2017).

Artificial ponds are an integral feature of an agricultural landscape (RAEBEL et al., 2012), but also to some extent a novel ecosystem and stepping stone habitats across the landscape (Simaika et al., 2016). One of the examples is the Bjelovar-Bilogora area with its ponds (mostly fishponds) incorporated into a traditionally agricultural landscape. Ponds contribute considerably to regional diversity in many parts of the world (Harabiš \& Dolný, 2011; Raebel et al., 2012; Kietzka et al., 2014; Simaika et al., 2016). Vilenica et al. (2020b) found that man-made water bodies with a well-developed riparian zone and aquatic vegetation as well as with low daily and seasonal water level fluctuations, can provide suitable habitats for different Odonata species. Although Simaika et al. (2016) found that artificial ponds increase the area of occupancy and population sizes of many generalist dragonfly species but attract no threatened or rare ones, some studies showed that anthropogenic habitats can be suitable habitats for protected species (RENner et al., 2016; HolTMAnN et al., 2018; VileniCA et al., 2020b). Moreover, man-made water bodies with suitable habitat conditions (favourable physico-chemical water properties and optimal vegetation structure) can even attract threatened species (VILENICA et al., 2016, 2020b).

This study aimed to inventory the dragonfly species of an artificial pond and its wider area by using the photographic approach and to provide baseline data for further study in the future.

\section{MATERIAL AND METHODS}

Gornje Plavnice is a settlement situated north of Bjelovar town in the continental part of Croatia. Jarak Pond is an artificial lake (fishpond) which was built in the 1980s in Gornje Plavnice; 45 56'26" N, 16 51'31' E, 149 m above sea level (see Fig. 2). Depth of the pond is about $1.5 \mathrm{~m}$. Fish species that inhabit this pond are: Ctenopharyngodon idella (Valenciennes, 1844), Carassius gibelio (Bloch, 1782), Hypophthalmichthys molitrix (Valenciennes, 1844), Abramis brama (Linnaeus, 1758), Ameiurus nebulosus (Lesueur, 1819), Cyprinus carpio Linnaeus, 1758, Hypophthalmichthys nobilis (Richardson, 1845), 
Silurus glanis Linnaeus, 1758, Esox lucius Linnaeus, 1758 and Lepomis gibbosus (Linnaeus, 1758), (ZŠRDUB, 2020). Data regarding Odonata were collected in a period between the $18^{\text {th }}$ of June 2017 and the $11^{\text {th }}$ of August 2020 along Jarak Pond as well as in the surrounding meadows, agricultural land and forest edge in Gornje Plavnice (see Fig. 1). Total surface area of the study area is approximately $24.030 \mathrm{~m}^{2}$, of which

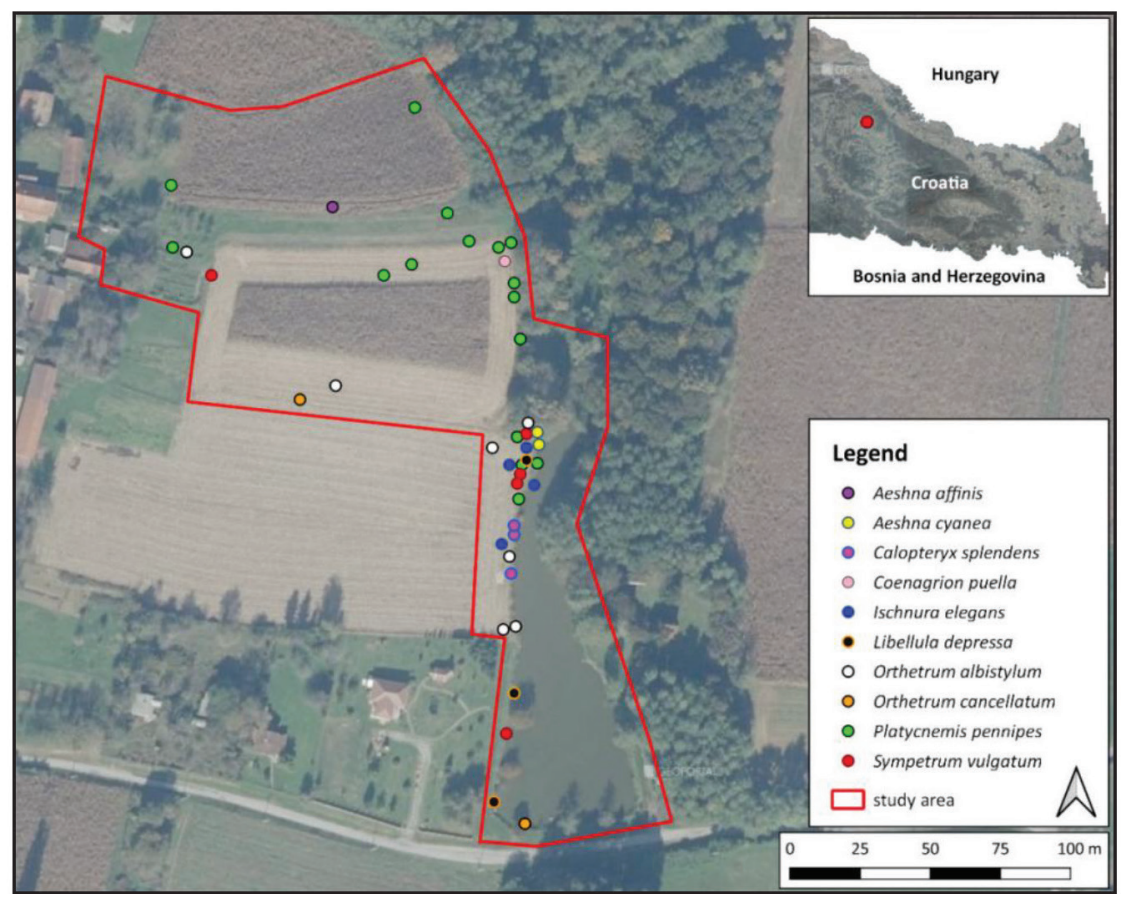

Fig 1. Locations in the study area where dragonfly species were recorded (layer source: GEOPORTAL, 2020).

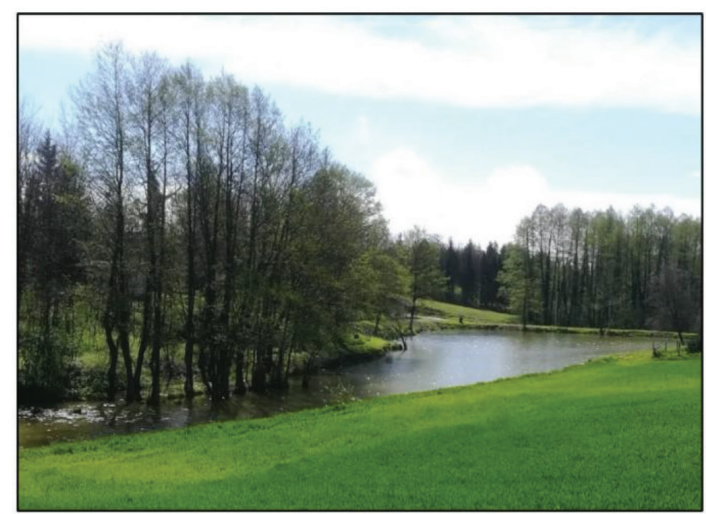

a)

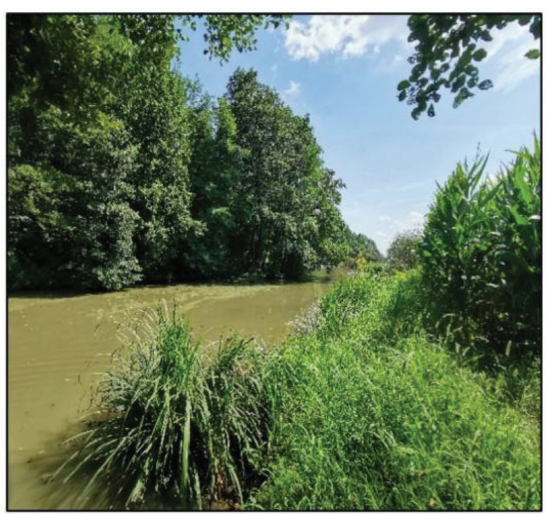

b)

Fig. 2. a) Middle and south part of Jarak Pond in Gornje Plavnice, Bjelovar and b) pond edge on the north part of Jarak Pond (photo: M. Veljković) 
the pond takes about $4.075 \mathrm{~m}^{2}$. The visits were under optimal circumstances (sunny, warm days when dragonflies are more active) and lasted until no additional species were found for half an hour. Dragonflies were mostly photographed from late morning (around 10 a.m.) to early afternoon (around 2 p.m.). However, visits were partly conducted during late afternoon because dragonflies are then less active so it is easier to get clearer photographs for species identification (https://www.habitas.org.uk). The focus was on the adult stage while larvae and exuviae were not sampled. Adults were observed and photographed by the author. Identifications were made using Dijkstra \& Lewington (2006) and the taxonomy follows the same literature. Reproductive behaviour of adults was also recorded. All collected photographs are stored in the author's private collection. Plant species were identified using STREeTER et al. (2016).

\section{RESULTS AND DISCUSSION}

With this study, 10 dragonfly species were recorded (see Tab. 1). Eight species were identified based on a total number of 1,060 high quality photographs. Two species - Aeshna affinis Vander Linden, 1820 and Aeshna cyanea (Müller, 1764) were identified by revision of high-quality videos collected during this field research because their great activity hinders the creation of reliable photographs for identification. Species that are documented by means of videos are excluded from the presentation of recorded species (Fig. 3 and Fig. 4). A list of recorded dragonfly species is presented in Tab. 1.

Among the recorded species, only Sympetrum vulgatum (Linnaeus, 1758) is listed in the Red Data Book of Dragonflies of Croatia (BELANČić et al., 2008) as Near Threatened (NT). Although the causes of its endangerment are still insufficiently known, it is NT in Croatia due to the effects of climate change but also because in Croatia, this species reaches the southern border of its distribution (BELANČić et al., 2008). In this study, the most common dragonfly species were Platycnemis pennipes (Pallas, 1771) and Orthetrum albistylum (Selys, 1848) while other species were less abundant. At the same time, P. pennipes was the most frequent Zygoptera species, while O. albistylum was the most frequent Anisoptera species in the study area. Platycnemis pennipes inhabits wide range of habitats; from floodplains, oxbows, rivers, open stretches of streams, lakes to man-made habitats like canals, gravel-pits and fishponds (MARTENS, 1996; Dijkstra \& Lewington, 2006). Larvae of this species are well adapted to fish predation (Steiner et al., 2000; Dijkstra \& Lewington, 2006), which is one of the main factors in structuring the odonate community of freshwater ecosystems (SIH, 1987; SteIner et al., 2000). Therefore the adaptation of $P$. pennipes to fish predation could explain its frequent presence in the study area. Orthetrum albistylum inhabits lakes and open ponds, usually with very scarce aquatic vegetation (AsKEw, 2004; DIJKSTRA \& Lewington, 2006; Vilenica \& Mihoci, 2018). It also occurs in fishponds (Vilenica \& Minoci, 2018) which it can also use as a breeding habitat (SMallshire \& Swash, 2020). As females of this species oviposit directly in water (Askew, 2004) and larvae of Orthetrum species lurk for prey from the sediment (CORBET \& BroOKs, 2008), the presence of aquatic vegetation is not a crucial habitat feature for this species (VILENICA et al., 2011, 2020b), so this could explain the records of O. albistylum at the pond edge with very little aquatic vegetation. Also, in the study area O. albistylum was frequent in the wider fishpond area including agricultural land and its edge where it was recorded 
Tab. 1. Systematic list of dragonfly species found in Gornje Plavnice (Bjelovar) with observation dates, sex and habitat where the species were recorded.

\begin{tabular}{|c|c|c|c|}
\hline Species & Observation date & Sex & Habitat \\
\hline \multicolumn{4}{|c|}{ Suborder: Zygoptera } \\
\hline \multicolumn{4}{|c|}{ Family: Calopterygidae } \\
\hline \multirow{3}{*}{$\begin{array}{l}\text { 1. Calopteryx splendens } \\
\text { (Harris, 1782) }\end{array}$} & 30.05 .2018 & female, male & pond edge \\
\hline & 04.06 .2018 & male & pond edge \\
\hline & 26.07 .2020 & male & pond edge \\
\hline \multicolumn{4}{|c|}{ Family: Coenagrionidae } \\
\hline \multirow{4}{*}{$\begin{array}{l}\text { 2. Ischnura elegans } \\
\text { (Vander Linden, 1820) }\end{array}$} & 28.05 .2018 & male & pond edge \\
\hline & 30.05 .2018 & tandem in copulation & pond edge \\
\hline & 24.06 .2019 & male & pond edge \\
\hline & 11.08 .2020 & male & pond edge \\
\hline $\begin{array}{l}\text { 3. Coenagrion puella } \\
\text { (Linnaeus, 1758) }\end{array}$ & 11.06 .2020 & male & forest edge \\
\hline \multicolumn{4}{|c|}{ Family: Platycnemididae } \\
\hline \multirow{16}{*}{$\begin{array}{l}\text { 4. Platycnemis pennipes } \\
\text { (Pallas, 1771) }\end{array}$} & 18.06.2017 & female & $\begin{array}{l}\text { edge of agricultural land, } \\
\text { agricultural land }\end{array}$ \\
\hline & 28.07.2017 & male & edge of agricultural land \\
\hline & 30.05 .2018 & male & edge of agricultural land \\
\hline & 30.05 .2018 & female & edge of agricultural land \\
\hline & 25.05.2019 & male & edge of agricultural land \\
\hline & 25.05 .2019 & teneral female & forest edge \\
\hline & 12.06 .2019 & teneral female & pond edge \\
\hline & 12.06 .2019 & male & meadow \\
\hline & 15.06.2019 & female & edge of agricultural land \\
\hline & 15.06 .2019 & male & edge of agricultural land \\
\hline & 24.06 .2019 & 3 males & forest edge \\
\hline & 24.06 .2019 & teneral female & pond edge \\
\hline & 20.07.2019 & tandem in copulation & edge of agricultural land \\
\hline & 21.07 .2019 & female & meadow \\
\hline & 05.08 .2019 & female & meadow \\
\hline & 26.07 .2020 & male & forest edge \\
\hline \multicolumn{4}{|c|}{ Suborder: Anisoptera } \\
\hline \multicolumn{4}{|c|}{ Family: Aeshnidae } \\
\hline $\begin{array}{l}\text { 5. Aeshna affinis Vander } \\
\text { Linden, } 1820\end{array}$ & 04.08 .2019 & male & $\begin{array}{c}\text { edge of agricultural land and } \\
\text { meadow }\end{array}$ \\
\hline \multirow{2}{*}{$\begin{array}{l}\text { 6. Aeshna cyanea } \\
\text { (Müller, 1764) }\end{array}$} & 06.11 .2018 & male & pond edge \\
\hline & 26.07 .2020 & male & pond edge \\
\hline \multicolumn{4}{|c|}{ Family: Libellulidae } \\
\hline \multirow{3}{*}{$\begin{array}{l}\text { 7. Libellula depressa } \\
\text { Linnaeus, } 1758\end{array}$} & 30.05 .2018 & male & pond edge \\
\hline & 28.05 .2018 & male & pond edge \\
\hline & 26.07 .2020 & male & pond edge \\
\hline \multirow{2}{*}{$\begin{array}{l}\text { 8. Orthetrum cancellatum } \\
\text { (Linnaeus, 1758) }\end{array}$} & 27.05 .2018 & female & edge of agricultural land \\
\hline & 04.06 .2018 & male & pond edge \\
\hline \multirow{7}{*}{$\begin{array}{l}\text { 9. Orthetrum albistylum } \\
\text { (Selys, 1848) }\end{array}$} & 28.05 .2018 & male & pond edge \\
\hline & 28.05 .2018 & female & agricultural land \\
\hline & 02.06 .2018 & female & edge of agricultural land \\
\hline & 04.06 .2018 & male & edge of agricultural land \\
\hline & 04.06 .2018 & female & forest edge \\
\hline & 08.06.2018 & female & agricultural land \\
\hline & 11.08 .2020 & male & pond edge \\
\hline \multirow{5}{*}{$\begin{array}{l}\text { 10. Sympetrum vulgatum } \\
\text { (Linnaeus, 1758) }\end{array}$} & 01.11 .2018 & tandem in copulation & agricultural land \\
\hline & 06.11 .2018 & tandem in copulation & pond edge \\
\hline & 06.11 .2018 & female & pond edge \\
\hline & 07.11 .2018 & male & pond edge \\
\hline & 06.11 .2018 & male & pond edge \\
\hline
\end{tabular}




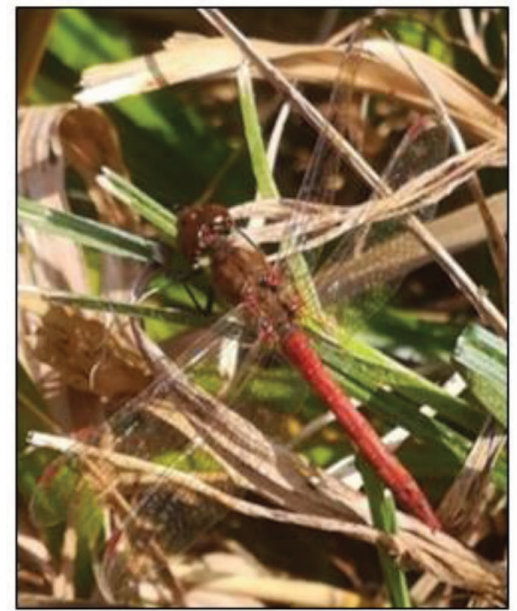

a)

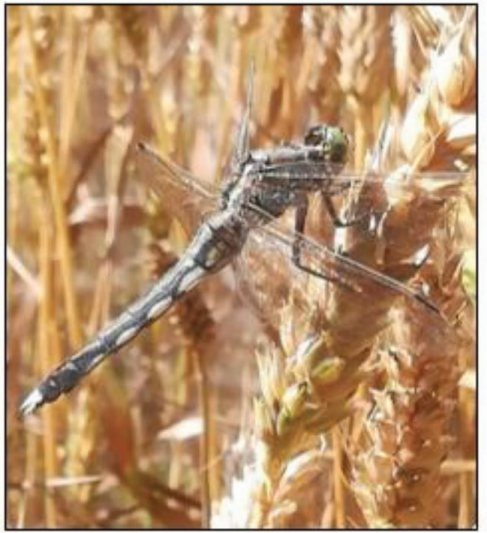

c)

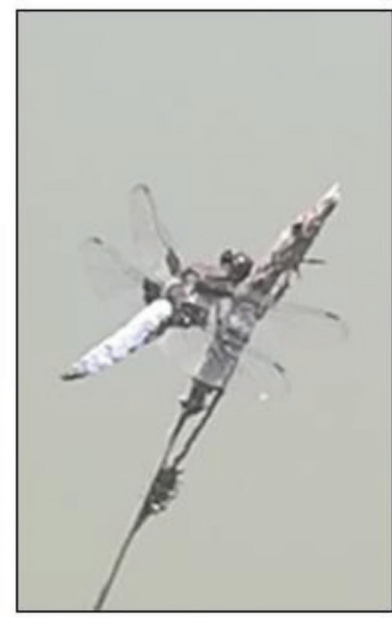

b)

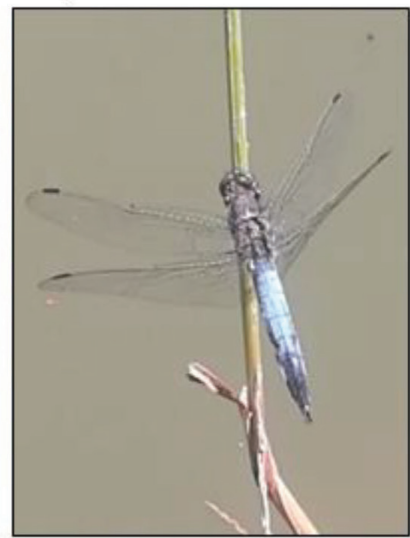

d)

Fig. 3. Dragonfly species (Odonata, Anisoptera) in the study area: a) male of Sympetrum vulgatum, b) male of Libellula depressa, c) female of Orthetrum albistylum, d) male of Orthetrum cancellatum (photo: M. Veljković)

while sitting on plants such as bread wheat (Triticum aestivum L.) (Fig. 3.c), perennial rye grass (Lolium perenne L.) or prickly sow-thistle (Sonchus asper (L.) Hill).

Most Odonata species were found at the pond edge (eight species), followed by the edge of agricultural land (four species). More species were observed on the vegetated pond edge (especially where Carex acuta L. is present) than on the less vegetated pond edge which confirms the importance of vegetation preference and structure for Odonata (Corbet \& Brooks, 2008; Vilenica et al., 2020b). Also, most of the recorded species were found on the shallower, northern part of the pond which is more remote from human impact and overgrown with riparian and aquatic vegetation. On the other hand, the southern part of the pond is under higher anthropogenic influence through occasional mowing of pond edge vegetation. Consequently, fewer species were recorded on this part of the pond. The more an area is affected by human activ- 


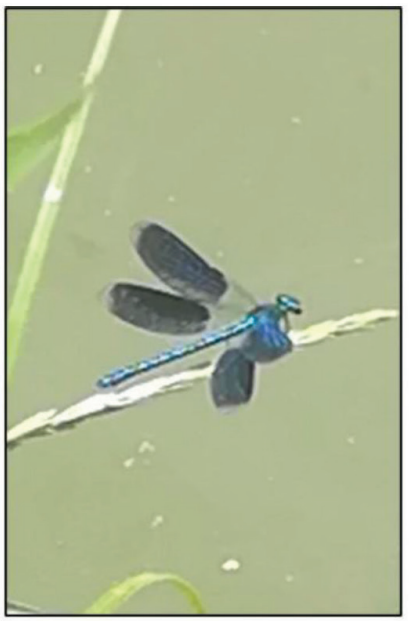

a)

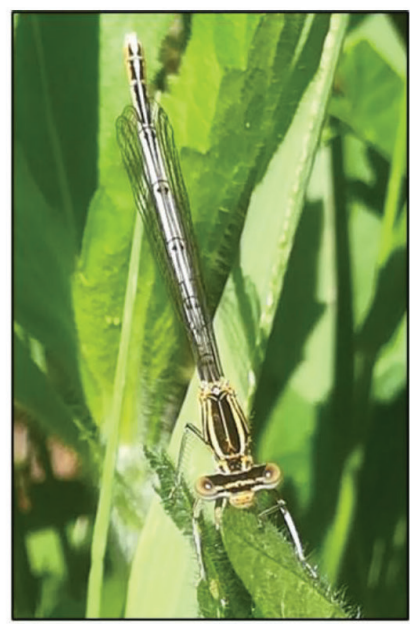

b)

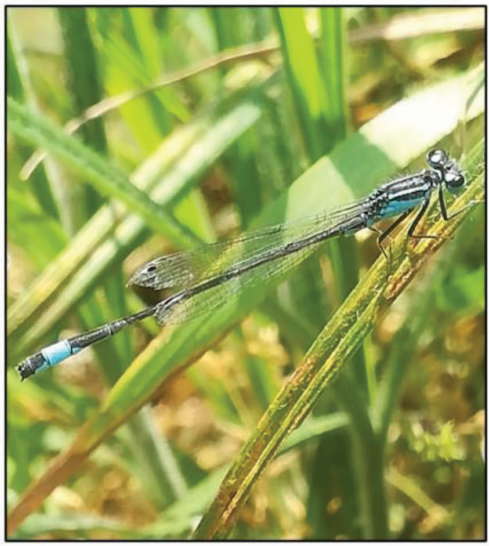

c)

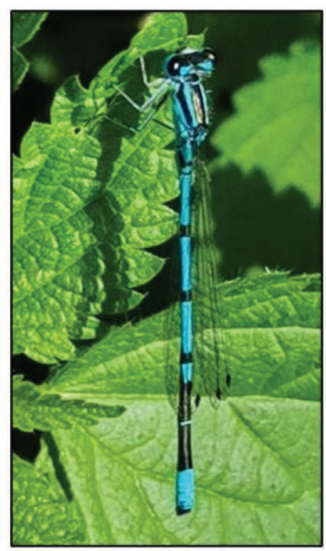

d)

Fig. 4. Damselfly species (Odonata, Zygoptera) in the study area: a) male of Calopteryx splendens, b) teneral female of Platycnemis pennipes, c) male of Ischnura elegans, d) male of Coenagrion puella (photo: M. Veljković)

ity, the fewer dragonfly species can be found there (Jomoc et al., 2013), and Zygoptera species are considered to be more vulnerable than Anisoptera (JANRA, 2018) as they remain in the vicinity of the site from which they have emerged. On the other hand, Anisoptera have much more advanced flying abilities which is why they can easily find new habitats (JANRA, 2018). In this study species were mostly observed between late morning (around 10 a.m.) and early afternoon (around 2 p.m.) while only specimens of $P$. pennipes, Ischnura elegans (Vander Linden, 1820) and O. cancellatum were also recorded in late afternoon (until around 7 p.m.). Although further research should be conducted, these results show that more dragonfly species can be photographed during the time of day when they are more active, even though getting quality photographs of individuals during this period is more demanding. 
Within the study, a rheophile Calopteryx splendens (Harris, 1782) was also observed. This species inhabits most open running waters but wandering males could often be recorded far from a suitable habitat (DiJKsTRa \& LEWINGTON, 2006). In the study area, males (Fig 4.a) and female were mostly recorded while resting on the pond edge vegetation. These individuals probably came from the small open stream which flows into Jarak Pond from its northern side. Individuals of $P$. pennipes were recorded at the fishpond edge but also on agricultural land (teneral female on the leaf of the Solanum tuberosum L.), edge of agricultural land (e.g. tandem in copulation), forest edge (e.g. males on the leaves of the Solidago canadensis L.) and on meadows in the study area. In earlier studies, individuals of $P$. pennipes were recorded on meadows at distances of up to 750 meters from waterbodies (WILD, 2017), so the observation of numerous individuals of $P$. pennipes on meadows and agricultural land in distances of up to 160 meters from Jarak Pond was not surprising. The flight season of this species is from the beginning of May to the end of September in central Europe, and it is especially busy in June and July (Dijkstra \& LeWIngton, 2006). In this study, most specimens were recorded in June while only one specimen was observed in August.

In this study, suborder Anisoptera was represented with two families: Aeshnidae and Libellulidae. Both families are mostly associated with standing or slow-flowing, often well-vegetated, water habitats, (DIJKSTRA \& LEwINGTON, 2006) which is probably the reason for their occurrence near the studied fishpond. Furthermore, Libellulidae is the most speciose Anisoptera family in Europe but also the largest family of European dragonflies (KALKman et al., 2010). In the study area Aeshnidae are represented by only two species: A. affinis and A. cyanea. Aeshna affinis prefers standing waterbodies which dry up during summer and are overgrown with bulrushes, low rushes and reeds (Dijkstra \& Lewington, 2006). The species (a male) was recorded only once, during a patrol of the edge of agricultural land and a meadow in August 2019. Aeshna cyanea breeds in a wide variety of waterbodies but prefers small, stagnant and shaded waterbodies like garden ponds or forest pools and is a common species in heavily forested and urban areas (DIJKSTRA \& LEWINGTON, 2006). It was a more frequent species in the study area than A. affinis. Only males were observed while patrolling along the pond edge. As vagile Anisoptera are much better fliers than the sedentary Zygoptera, they can often search for and use additional habitats away from their emergence sites (Samways \& Niba, 2010; Simaika et al., 2016). So, it is possible that the males of $A$. affinis and $A$. cyanea observed in the study area, had migrated from other local populations but for more conclusions further research should be conducted.

Orthetrum albistylum and S. vulgatum were the most frequently found species from the family Libellulidae in the study area. Some photographs ere unreliable in that they could not show the key characteristics for identification, and accordingly some species from the family Libellulidae were excluded from the species list. Therefore, the number of species in the study area could be higher, which should be examined with further research. Sympetrum vulgatum is one of the most common dragonflies in eastern and northern Europe, while its distribution also spreads deep into northern Asia (Dijkstra \& Lewington, 2006). The species' flight season is between June and November, but most records were reported from July to September. Sympetrum vulgatum inhabits all kinds of standing water habitats (DIJKSTRA \& LEWINGTON, 2006). During this study, it was recorded only in November 2018, mostly on the pond edge (see Fig. 3.a). Two records showed a copulation tandem near the pond edge and on 
the agricultural land, while other individuals were recorded on the pond edge. Also, a teneral female and a male of $S$. vulgatum were recorded in the vicinity of the study area during July and September 2017 (see VelJKović, 2018). It is possible that observed individuals of $S$. vulgatum represent vagrant individuals that originate from elsewhere in the wider region, but for correct conclusions more targeted research should be conducted.

The studied habitats could be suitable for some other dragonfly species that were not recorded during this study. The fishpond in the study area is partly surrounded by forest, so Zygoptera species like Lestes viridis (Vander Linden, 1825) and Lestes parvidens Artobolevskii, 1929 that inhabit almost any type of slow-flowing or standing water with bordering trees and bushes (Dijkstra \& LEWINGTON, 2006) could occur there. Furthermore, Sympecma fusca (Vander Linden, 1820), which inhabits all kinds of well-vegetated standing waters (Dijkstra \& LEWINGTON, 2006), could also occur here. Adults of this species can be seen throughout the year but are most reproductively active in April and May. A peak of their activity is in August and September (DIJKSTRA \& Lewington, 2006). This study was not conducted during April and during most of May so it is possible the species was missed in this period, while it might have been overlooked in the second part of its flight activity. Anisoptera species such as Aeshna grandis (Linnaeus, 1758), which usually occur in forested areas and breed in a wide range of calm waters (like oxbows, abandoned canals, fenlands, etc.) with rich bankside or submerged vegetation (Dijkstra \& Lewington, 2006; Belančić et al., 2008) and Anax imperator Leach, 1815, which inhabits standing, well-vegetated waters (Dijkstra \& Lewington, 2006), could also be expected in the study area. Furthermore, Aeshna mixta Latreille, 1805, which breeds in a wide range of still and slow-flowing waters with riparian vegetation, but may be found anywhere when hunting or migrating, Libellula quadrimaculata Linnaeus, 1758, which inhabits most still waters, especially with well-developed vegetation and Sympetrum sanguineum (Müller, 1764), which inhabits most waters with lush marshy vegetation (DIJKSTRA \& LEwINGTON, 2006) could also be expected in the study area. The studied habitats could also be suitable for Aeshna isoceles (Müller, 1767), which inhabits ponds, ditches, marshes and lakes with rich vegetation as well as for Cordulia aenea (Linnaeus, 1758) and Epitheca bimaculata (Charpentier, 1825), which inhabit standing waters, including fishponds (Dijkstra \& LeWington, 2006).

The main threats to freshwater biota are habitat loss, diverse anthropogenic habitat alterations and pollution (Thomas et al., 2004; Vilenica et al., 2020b). One of the major threats to the dragonfly species in the study area is agricultural intensification because nowadays agricultural land that stretches along to the pond has expanded and now reaches the pond edge. Consequently, the width of the pond edge is at some parts reduced to less than $0.5 \mathrm{~m}$. Furthermore, periodical mowing of pond edge vegetation (including Carex acuta) as well as treating crops with herbicides and pesticides on agricultural land along the pond edge where the most dragonfly species were found, could affect the occurrence and survival of dragonflies that breed and/or feed there. Globally, extensive urbanization, agriculture and industry, large quantities of pesticides, industrial and domestic waste as well as pharmaceuticals that are discharged daily into freshwater habitats negatively influence populations of many aquatic organisms, including Odonata (ZhAng et al., 2004; Arimoro et al., 2008; VilenICA et al., 2020a). Also, a high level inflow of nutrients from agricultural land into the pond supports excessive growth of aquatic macrophytes and algae, resulting in low 
oxygen concentrations in the waterbody which consequently limits Odonata presence in influenced habitats (Rose \& Crumpton, 1996; Boeykens et al., 2017; Vilenica et al. 2020a).

This research provides additional knowledge about the possibilities of photographic research into dragonflies, obviating the need for the collection of dragonfly specimens. However, the results of this photographic research have a preliminary character so they should be a starting point for further research. Although further research into the importance of Jarak Pond and its wider area for Odonata species is needed, results of this research show that this pond is one more example of how man-made water bodies, with well-developed riparian and aquatic vegetation as well as with low daily and seasonal water level fluctuations, can provide suitable habitats for different species of Odonata (VILENICA et al., 2020b), especially in an agriculturally fragmented landscape. Although mostly generalist species were recorded in the study area, the conservation of the total assemblage is also important as in the future some may become rare (Simaika et al., 2016). In conclusion, more recent knowledge about dragonfly fauna in the Bjelovar-Bilogora area (including artificial ponds) is needed, in order to manage conservation methods to sustain the biodiversity and stability of dragonfly populations under different threats such as agricultural intensification, abandonment of traditional agriculture, global climate crisis, etc.

\section{ACKNOWLEDGEMENTS}

I would like to thank Toni Koren, PhD and Ana Štih, mag. biol. exp. from the Hyla Association, Zagreb as well as Assistant Professor Marina Vilenica, PhD (Faculty of Teacher Education, University of Zagreb) for revision of dragonfly identification in this study.

Received October 19, 2020

\section{REFERENCES}

Arimoro, F. O., Chunwuji, M. A. I. \& Ogheneghalome, O., 2008: Effects of industrial waste water on the physical and chemical characteristics of a tropical coastal river. Research Journal of Environmental Sciences 2 (3), 209-220.

Askew, R. R., 2004: The dragonflies of Europe, Second Edition, Harley Books, Essex. 308 p.

Belančić, A., Bogdanović, T., Franković, M., Ljuština, M., Mihoković, N. \& Vitas, B., 2008: Red Data Book of Dragonflies of Croatia. Ministry of Culture, State Institute for Nature Protection, Zagreb. $132 \mathrm{p}$.

Boeykens, S. P., Piol, M. N., Legal, L. S., Saralegui, A. B. \& Vázquez, C., 2017: Eutrophication decrease: Phosphate adsorption processes in presence of nitrates. Journal of Environmental Management 203, 888-895.

BUGGUIDE. Available at: https://bugguide.net/node/view/15740. Accessed on 29 August 2020.

Corbet, P. \& Brooks, S. 2008: Dragonflies, Collins New Naturalist Library No 106. London: HarperCollins. $480 \mathrm{p}$.

CROATIAN CHECK LIST OF ODONATA. Available at: https://www.botanic.hr/cisb/Edoc/fauna/ odonata/odopornovi.htm. Accessed on 29 August 2020.

Day, L., Farrell, D., Gibert, E., Günther, A., Hämäläinen, M., Klimsa, E., Korshunov, A., Kosterin, O., Makbun, N., Pelegrin, A., Röder, U., Ruangrong, R. \& Vikhrev, N., 2012: New provincial records of Odonata from Thailand mostly based on photographs. Agrion 16 (1), 16-25. 
Dijkstra, K.-D. B. \& Lewington, R., 2006: Field Guide to the Dragonflies of Britain and Europe including western Turkey and north-western Africa. Bloomsbury Wildlife, London. 320 p.

Galliani, C., Scherini, R. \& Piglia, A., 2017: Dragonflies and Damselflies of Europe, A scientific approach to the identification of European Odonata without capture. WBA Handbooks 7, Verona. $347 \mathrm{p}$.

GEOPORTAL, 2020: Digitalni ortofoto 2019 - WMS servis. Available at: https://geoportal.dgu.hr/ services/inspire/orthophoto_2019/wms). Accessed on 07 August 2020.

Harabiš, F. \& DolnÝ, A., 2011: Human altered ecosystems: Suitable habitats as well as ecological traps for dragonflies (Odonata): The matter of scale. Journal of Insect Conservation 16 (1), 121-130.

Holtmann, L., Juchem, M., Brüggeshemke, J., Möhlmeyer, A. \& Fartmann, T., 2018: Stormwater ponds promote dragonfly (Odonata) species richness and density in urban areas. Ecological Engineering 118, 1-11.

INATURALIST. Available at: https:/ /www.inaturalist.org/. Accessed on: 29 August 2020.

Janra, M. N., 2018: Inventory of Dragonflies and Damselflies (Odonata) in Andalas University's Limau Manis Campus Complex, Padang: Using Photographical Approach. Journal Natural 18(2), DOI 10.24815/jn.v18i2.11133.

Jomoc, D. J. G., Flores, R. R. C., Nuñeza, O. M. \& Villanueva, R. J. T., 2013: Species richness of Odonata in selected wetland areas of Cagayan de Oro and Bukidnon, Philippines. Aquaculture, Aquarium, Conservation \& Legislation, International Journal of the Bioflux Society 6(6), 560-570.

Kalkman, V. J., Boudot, J.-P., Bernard, R., Conze, K.-J., De Knijf, G., Dyatlova, E., Ferreira, S., Jović, M., Ott, J., Riservato, E. \& Sahlén, G., 2010: European Red List of Dragonflies. Luxembourg: Publications Office of the European Union.

Kietzka, G. J., Pryke, J. S. \& Samways, M. J., 2014: Landscape ecological networks are successful in supporting adiverse dragonfly assemblage. Insect Conservation and Diversity 8, 229-237.

Martens, A., 1996: Die Federlibellen Europas (Platycnemididae). Die Neue-Brehm Bücherei 626. Westarp Wissenschaften, Magdeburg and Spektrum, Heidelberg.

Raebel, E. M., Merckx, T., Feber, R. E., Riordan, P., Thompson, D. J. \& Macdonald, D. W., 2012 : Multi-scale effects of farmland management on dragonfly and damselfly assemblages of farmland ponds. Agriculture, Ecosystems \& Environment 161, 80-87.

Renner, S., Périco, E. \& SAhlén, G., 2016: Man-made lakes form species-rich dragonfly communities in the Brazilian Atlantic Forest (Odonata). Odonatologica 45 (3), 135-154.

Rose, C. \& Crumpton, W. G., 1996: Effects of emergent macrophytes on dissolved oxygen dynamics in a prairie pothole wetland. Wetlands 16, 495-502.

Samways, M. J. \& Niba, A. S., 2010: Climate and elevation range of South African dragonfly assemblage. BioRisk 5, 85-107.

Sснміdт, E. G., 1982: Libellenfotos als Beleg für die Artbestimmung. Libellula 1 (2), 40-48.

Sснміdт E. G., 1995: Key for determination of dragonflies by sight and by foto-documents, pp. 63-70. - XIII. International Symposium of Odonatology Essen, 20.-25.8.1995, Essen.

Seehausen, M., Pinto, R. M. S., Trainor, C. R. \& Lopes, J. P., 2018: Further records of Odonata from Timor Island, with the first photographs of living Nososticta impercepta (Odonata: Platycnemididae) and additional records from Rote and Romang Islands. Journal of the International Dragonfly Fund 25, 1-73.

Sin, A., 1987: Predators and prey lifestyles: an evolutionary and ecological overview. In KerfoOT, W. C. \& A. Siн (eds), Predation: Direct and Impacts on Aquatic Communities. New England University Press, Hanover, 203-224.

Simaika, J. P., Samways, M. J. \& Frenzel, P. P., 2016: Artificial ponds increase local dragonfly diversity in a global biodiversity hotspot. Biodiversity and Conservation 25 (10), 1921-1935.

Smallshire, D. \& Swash, A., 2020: Europe's dragonflies, A field guide to the damselflies and dragonflies. Princeton University Press, 41 William Street, Princeton, New Jersey 08540; In the United Kingdom: Princeton University Press, 6 Oxford Street, Woodstock, Oxfordshire OX20 1TR.

Sribal, U., Paweenpermsuk, Y., Thitiarchagul, T., Atdhabhan, S., Saengamorn, C., Thepphibalsathit, N., Chaychum, S., Behrstock, R. A., Jadoonkittinan, P., Ruangrong, R., Ruangrong, J., Thammasangwan, N., Tesring, S., Chanhong, S., Makbun, N., 2018: New national records of Odonata from Thailand based mostly on photographs (Odonata: Argiolestidae, Philosinidae, Aeshnidae, Libellulidae). Agrion 22(1), 30-36. 
Steiner, C., Siegert, B., Schulz, S. \& Suhling, F., 2000: Habitat selection in the larvae of two species of Zygoptera (Odonata): biotic interactions and abiotic limitation. Hydrobiologia 427, 167-176.

Streeter, D., Hart-Davies, C., Hardcastle, A., Cole, F. \& Harper, L., 2016: Collins Wild Flower Guide. The most complete guide to the wild flowers of Britain and Ireland. HarperCollins Publishers, London. $704 \mathrm{p}$.

Thomas, J. A., Telfer, M. G., Roy, D. B. et al., 2004: Comparative losses of British butterflies, birds, and plants and the global extinction crisis. Science 303, 1879-1881.

Veljković, M., 2018: First record of the moustached darter Sympetrum vulgatum (Linnaeus, 1758) (Odonata: Libellulidae) for the Bjelovar area, Croatia. Natura Sloveniae 20(1), 59-60.

Vilenica, M., MičEtić Stanković, V. \& Franković, M., 2011: Dragonfly fauna (Insecta, Odonata) in the Turopolje region (Croatia). Natura Croatica 20 (1), 141-158.

Vilenica, M., Alegro, A., Koletić, N. \& Mihaljević, Z., 2016: New evidence of Lindenia tetraphylla (Vander Linden, 1825) (Odonata, Gomphidae) reproduction at the north-western border of its distribution. Natura Croatica 25 (2), 287-294.

Vilenica, M. \& MiHOCI, I., 2018: Odonata collection of the Croatian Natural History Museum. Natura Croatica 27 (1), 153-184.

Vilenica, M., Kerovec, M., Pozojević, I. \& Mihaljević, Z., 2020a: Odonata assemblages in anthropogenically impacted lotic habitats. Journal of Limnology. https:/ / doi.org/10.4081/jlimnol.2020.1968.

Vilennica, M., Pozojević, I., VučKović, N. \& Mihaljević, Z., 2020b: How suitable are man-made water bodies as habitats for Odonata? Knowledge \& Management of Aquatic Ecosystems 421 (13), 1-10 DOI: $10.1051 / \mathrm{kmae} / 2020008$.

WILD, N., 2017: Spatio-temporal patterns of dragonfly occurrence on meadows in the Donau-Auen National Park, Lower Austria. $6^{\text {th }}$ Symposium for Research in Protected Areas, Salzburg, 727-732. www.habitas.org.uk/dragonflyireland/methods.htm

ZAJEDNICA ŠPORTSKO RIBOLOVNIH DRUŠTAVA I UDRUGA BJELOVAR (ZŠRDUB), 2020: Available at: https://zsrdub.hr/ribolovne-vode/hrvatska/jarak-gornje-plavnice. Accessed on 29 August 2020.

Zhang, Z., Huang, J., Yu, G. \& Hong, H., 2004: Occurrence of PAHs, PCBs and organochlorine pesticides in the Tonghui river of Beijing, China. Environmental Pollution 130 (2), 249-261. 